\title{
Antoni Stankiewicz
}

\section{Natura procesu beatyfikacyjnego i kanonizacyjnego}

Prawo Kanoniczne : kwartalnik prawno-historyczny 8/2, 69-90

1965

Artykuł został zdigitalizowany i opracowany do udostępnienia w internecie przez Muzeum Historii Polski w ramach prac podejmowanych na rzecz zapewnienia otwartego, powszechnego i trwałego dostępu do polskiego dorobku naukowego i kulturalnego. Artykuł jest umieszczony w kolekcji cyfrowej bazhum.muzhp.pl, gromadzącej zawartość polskich czasopism humanistycznych i społecznych.

Tekst jest udostępniony do wykorzystania w ramach dozwolonego użytku. 


\section{NATURA PROCESU BEATYFIKACYJNEGO I KANONIZACYJNEGO}

Kodeks Prawa Kanonicznego omawia postępowanie w sprawach beatyfikacji i kanonizacji w IV księdze, traktującej o procesach. Ponieważ jednak w księdze tej jest mowa zarówno o procesach sądowych, jak również o procesach administracyjnych, powstaje pytanie, jaką naturę posiada proces beatyfikacyjny i kanonizacyjny.

\section{$\S 1$. Dawne prawo}

Przed XIII wiekiem trudno dopatrzyć się formalnej procedury $w$ postępowaniu o stwierdzenie świętości sług Bożych, a to ze względu na stosunkowo niewielki materiał historyczny, jaki przetrwał do naszych czasów oraz z powodu braku decyzji ustawodawczych, regulujących postępowanie w tych sprawach ${ }^{1}$.

$\mathrm{Na}$ skutek wprowadzenia zasady procesu pisanego $\mathrm{w}$ XIII wieku, wiele procesów $\mathrm{z}$ tego okresu dochowało się do naszych czasów, z których można wnioskować, że w postępowaniu o uznanie za świętego stosowano normy procesu sądowego?.

I Por. Acta SS OSB, t. III, 164; Acta SS Januarii t. III, s. 363. Szczegółowe omówienie tego zagadnienia przedstawiłem $w$ pracy: Sędziowie $w$ beatyfikacyjnym przewodzie na terenie diecezji, Lublin 1961 (maszynopis), s. 22-49.

2 Innocenty III na IV soborze laterańskim w 1215 r. w c. 38 postanowil: ...ut tam in ordinario iudicio quam extraordinario, iudex semper adhibeat aut publicam si fieri potest personam, aut duos viros idoneos qui fideliter iudicii acta conscribant - c. 11, X, II, 19; We rnz F., Ius decretalium, t. V, Romae 1905, n. 130; Roberti F., De processibus, t. I, In civitate Vaticana $1956^{4}$, s. 281 . 
Pogląd ten znajduje również potwierdzenie w fakcie, że decyzje papieskie $z$ dziedziny postępowania kanonizacyjnego wchodziły nieraz do ogólnych norm kościelnych procesu ${ }^{3}$. Wypadek taki zaistniał w 1225 r. za pontyfikatu Honoriusza III ${ }^{4}$. Kiedy bowiem sędziowie $\mathrm{w}$ procesie apostolskim przesłali do Honoriusza III zaprzysiężone zeznania świadków $w$ sprawie św. Maurycjusza, papież odmówił im mocy dowodowej, a sędziom polecił ponownie przesłuchać tych samych świadków. Przyczyną negatywnej oceny zeznań okazał się ten fakt, że $\mathrm{w}$ toku procesu sędziowie nie przesłuchali świadków pojedyńczo. Jest rzeczą charakterystyczną, że ta decyzja papieska przeszła do urzędowego zbioru prawa kościelnego: Dekretałów Grzegorza IX, stając się odtąd normą z dziedziny prawa procesowego ${ }^{5}$.

Począwszy od XVII wieku, w decyzjach papieskich dotyczących beatyfikacji i kanonizacji wyraźnie występują terminy, świadczące o podobieństwie procesu beatyfikacyjnego i kanonizacyjnego do procesu sądowego. I tak Urban VIII (1623-1644) w dekretach reformujących postępowanie beatyfikacyjne i kanonizacyjne używa takich terminów: processus ${ }^{6}$, probationes ${ }^{7}$, judicialiter ${ }^{8}$.

3 Por. Blaher D. J., The Ordinary Processes in Causes of Beatification and Canonization, Washington 1949, s. 14.

4. B aroni i C., Annales Ecclesiastici, t. XX, Romae 1592, ad ann. 1225 , n. $49=$ c. $52, \mathrm{X}, \mathrm{II}, 20:$,,Venerabili fratri nostro et capitulo Corisopitensi, ac universis abbatibus apud Cistercium in generali capitulo congregatis... Discretioni vestrae mandamus, quatenus testes, quos abbas et monachi S. Martini Cisterciensis ordinis super vita et miraculis piae memoriae $M$. abbatis monasterii supradicti duxerint producendos, examinare singillatim curetis cum ea diligentia, quae solet et debet in receptione testium adhiberi".

5 B laher D. J., op. cit., s. 14.

- Ur banus VIII, cons. Coelestis Hierusalem, 5 jul. 1634, Fontes J. C., t. I, n. 213: ,...processum instrueret, vel huc usque receptas informationes instructumve processum ulterius prosequeretur...". Należy zaznaczyć, że termin: „processus” został wprowadzony przez prawo kanoniczne na oznaczenie czynności sądowych, zwłaszcza sędziego, $\mathrm{w}$ odróżnieniu od przedmiotowych norm procesu $\mathrm{zw}$. ordo iudiciarius i osób, pomiędzy którymi zachodzi stosunek procesowy - por. Roberti F., op. cit., t. I, s. 73. 
W dekretach Innocentego XI (1676-1689) znajdujemy również liczne terminy spotykane $w$ procesie sądowym, które w postępowaniu beatyfikacyjnym i kanonizacyjnym posiadały analogiczne znaczenie, np. juramentum ${ }^{9}$, judices, notarii, testes ${ }^{10}$. partes ${ }^{11}$, periti ${ }^{12}$, taxae ${ }^{13}$ i.t.d.

To samo można powiedzieć $\mathrm{w}$ odniesieniu do dekretów następnych papieży, jak: Benedykta XIV (1740-1758) ${ }^{14}$, Klemensa XIII (1758-1769) ${ }^{15}$ oraz Piusa IX (1846-1878) ${ }^{16}$.

$\mathrm{Na}$ tej podstawie autorowie przedkodeksowi $\mathrm{w}$ postępowaniu beatyfikacyjnym i kanonizacyjnym upatrywali natury procesu sądowego, chociaż wyrażali rozmaite zapatrywania jeśli chodzi

7 Fontes J. C., t. I, n. 213: „...per, legitimas juridice susceptas probationes circa personam eius... docuerit".

8 Ibid.; "...ac deinde nobis judicialiter aperiendi eos processus facultas indulta fuisset".

9 Decreta Novissima S. R. Congreg. edita jussu S. M. Innocentii XI, 15 oct. 1678, Fontes J. C., t. VII, n. 5626: „...debeant ante inchoationem processus praestare juramentum de servando secreto religiose...".

10 Ibid.: ,....idem judices... et notarii... ac testes...".

11 Ibid.: ,...ut liceat partibus in quocumque statu causae...".

12 Ibid.: „...per peritos eiusdem professionis...".

13 Ibid.: „Sacra Congregatio jussit servari taxas ab ea dilligenter revisas...".

Dochodzenia procesowe $\mathrm{w}$ wymienionym dekrecie określa się terminem: „inquisitio".

14 Pomijając wiekopomne dzieło tego papieża: De Servorum Dei beatificatione et Beatorum Canonizatione, t. I-IV, Romae 1747, w którym omówił całokształt postępowania w sprawach beatyfikacji i kanonizacji, $w$ dekrecie $z$ dnia 23 kwietnia 1741 r. stwierdza: ,...ne juris rigor in his causis adhiberi nedum solitus, sed necessarius ullo pacto relaxetur..." (Fontes J. C., t. VII, n. 5779).

15 Clemens XIII, ep. Efflagitari, 16 aug. 1763, Codex pro postulatoribus, Romae 1929, Appendix VI, s. 306-307: „Ordinariorum solum est onus examinari sintne vere in aliquo ex casibus a memorato praedecessore Nostro Urbano exceptis... atque... poterunt ferre sententiam, quae in his casibus Apostolica confirmatione non indigent...". Charakterystyczne jest tu wyrażenie: ferre sententiam.

16 S.R.C., decr. 10 dec. 1868, Fontes J. C., t. VIII, n. 6034: „Subinde tamen, accedente expresso vel tacito $S$. Sedis consensu iudicialis illa ac legitima inquisitio intermitti coepit...". W tym dekrecie jest znowu charakterystyczne wyrażenie: iudicialis inquisitio. 
- szczegółowy sposób ujęcia natury tego procesu. Contelori utrzymywał, że sprawy kanonizacyjne, zwłaszcza zaś dowodzenie $w$ procesie kanonizacyjnym upodobnia się do spraw cywilnych ${ }^{17}$. De Matta znowu uważal, że dowodzenie w procesie kanonizacyjnym podobne jest dowodzeniu w procesie karnym, w którym winno ono być jaśniejsze od dziennego światła ${ }^{18}$. Rosa zaś wyrażał opinię, że sprawy kanonizacyjne w początkowej fazie postępowania przynależą do spraw spornych. Jednakże twierdził, że sporny charakter tych spraw trwa jedynie do momentu, w którym papież przystąpi do wydania ostatecznej decyzji, gdyż $z$ tą chwilą kanonizacja przechodzi $w$ sfere wpływu czynnika nadnaturalnego i traci tym samym swój sporny charakter ${ }^{19}$.

Wymienieni powyżej autorowie, zasugerowani zewnętrznym porządkiem sądowym, przestrzeganym $w$ sprawach beatyfikacji i kanonizacji, wnosili o sądowej ich naturze, chociaż używane przez nich wyrażenia: „assimilentur" lub „pertinere” dowodzą, iż zdawali sobie sprawę $z$ ich odrębności oraz swois-

17 Contelori F., Tractatus et praxis de canonizatione Sanctorum, Lugduni $1634^{2}$, cap. 18, n. 25: ,...probationes in causa canonizationis parificari probationi in causa civili...".

${ }_{18}$ De M atta, Novissimus de canonizatione Sanctorum tractatus, Bononiae 1628, p. 4, cap. 1, 10: ,...probationes in causis Canonizationum parificari probationibus causarum potius criminalium..., quia causae canonizationis sunt de majoribus..., et cum sint tales indigent concludenti et pernecessaria probatione, et luce meridiana clariore, prout observatur in criminalibus...".

19 R os a T., Additiones ad suum tractatum de executoribus litterarum tam gratiae quam iustitiae cum tractatu de executoribus litterarum remissorialium in ordine ad processus pro canonizatione Sanctorum, Lugduni 1737, cap. 1, n. 20: „Has canonizationum causas in principio ad naturam contentiosarum pertinere...., quod evidenter patet tam ex ceremonialis Leonis in principio, quam et clarius ex decretis S. M. Urbani VIII et forma commisionis, seu remissorialium..."; n. 21: "...quibus tamen expletis cessat hujusmodi natura contentiosi iudicii, et definitionem ex cathedra, quam facit S. Pontifex, ad Spiritus Sanctí inspirationem referendam esse...". Zdanie to wypowiadal Rosa, idac w zasadzie za nauką głoszoną przez De Matta. 
tego charakteru ${ }^{20}$. Wnikliwe spojrzenie na tę kwestię wyraził Benedykt XIV, twierdząc, że w sprawach beatyfikacji i kanonizacji został wprowadzony porządek sądowy, ponieważ służy on najlepiej do wykrycia prawdy ${ }^{21}$.

Należy także zaznaczyć, że niektórzy spośród autorów przedkodeksowych utrzymywali, że proces beatyfikacyjny i kanonizacyjny stanowi szczególny porządek postępowania (ordo peculiaris) ${ }^{22}$.

Reasumując powyższe wywody trzeba stwierdzić, że o ile autorowie w XVI w. mówią wyraźnie o spornej naturze procesu beatyfikacyjnego i kanonizacyjnego, o tyle późniejsi kanoniści już wyraźnie zdają sprawę ze specyficzności tego procesu, określając go nazwą postępowania specjalnego ${ }^{23}$.

\section{$\S$ 2. Prawo kodeksowe}

Kodeks Prawa Kanonicznego poświęca postępowaniu w sprawach beatyfikacji i kanonizacji całą część drugą księgi IV,

20 R os a T., op. cit., n. 22: „...sed sive contentionibus civilibus sive criminalibus hujusmodi Canonizationum causae assimilentur, certum omnino est, quod in illis maxima attentione et cricumspectione procedendum est utpote in causis maximi momenti, tamquam de gravioribus Ecclesiae militantis...".

21 Benedictus XIV, op. cit., I, 46, 10: ,...statuto in causis beatificationis et canonizationis ordine iudiciali, tamquam ad rerum veritatem eruendam aptiore...".

22 Wernz F., op. cit., t. III, n. 373: „...methodus quaedam adhibenda fuerit statuta ad similitudinem ordinis iudiciarii..."; L a ure nti us J., Institutiones Iuris Ecclesiastici, Friburgi Brisgoviae 1914 3 , s. 585: „Processus beatificationis et canonizationis ordinem peculiarem habet...". Por. także B ang e n J. H., Die Römische Curie ihre gegenwärtige Zusamensetzung und ihr Geschäftsgang, Münster 1854, § $66 \mathrm{nn}$.

23 Najprawdopodobniej takie stanowisko zostalo podytkowane jasnym wyrażeniem, sformułowanym w dekrecie Sw. Kongregacji Obrzędów z dnia 11 listopada $191 \overline{2}$ r. (Fontes J. C, t. VIII, n. 6389): „...In omnibus et singulis causis procedentibus per viam casus excepti, abrogato penitus alio iudiciali ordine, ante omnia, more solito perquirantur diligenterque recognoscantur scripta Servi Dei...”. 
traktującej o procesie kościelnym ${ }^{24}$. Umieszczenie jednak postępowania beatyfikacyjnego i kanonizacyjnego $w$ zespole kościelnych procesów nie wyeliminowało dyskusji nad jego naturą. U autorów pokodeksowych zarysowuje się $w$ tej kwestii wielorakość poglądów.

1. Niektórzy spośród autorów dopatrują się w postępowaniu beatyfikacyjnym i kanonizacyjnym natury procesu sądowego. Takiego poglądu można dopatrzyć się w stanowisku, które zajmują: Muniz ${ }^{25}$, Beste ${ }^{26}$, Indelicato ${ }^{27}$, Padacz ${ }^{28}$, Lisowski ${ }^{29}$. Nie znaczy to, jakoby ci autorowie nie dostrzegali żadnej różnicy między procesem sądowym i procesem beatyfikacyjnym; niemniej jednak dopatrują się $w$ nich elementu spornego oraz wszystkich czynników wchodzących w skład procesu sądowego ${ }^{30}$.

24 Codex Iuris Canonici, Liber quartus De Processibus, pars secunda De causis beatificationis Servorum Dei et canonizationis Beatorum, can. $1999-2141$.

${ }_{25}$ M uniz T., Procédimientos Ecclesiasticos, t. III, Sevilla (1926) ${ }^{2}$, s. 584: „Les causas de Beatificación y Canonización son estrictamente judiciales y se elevan en juicio contradictorio, „por to cual requiren actor o demadente y demandado...".

26 Beste U., Introductio in Codicem, Collegeville 1938, s. 755.

27 Indelicato S., Il processo apostolico di beatificazione, Roma 1945, s. 171: ,...le cause beatificazione e canonizzazione appaiono di loro natura contenziose...".

${ }_{28} \mathrm{Padacz}$ W., Beatyfikacyjny przewód sqdowy, Ateneum Kapłańskie, LI(1949)152: „Aby Sługa Boży dekretem Stolicy Apostolskiej uznany został za błogosławionego, potrzebny jest beatyfikacyjny proces sądowy".

29 Lis owski J., Kanonizacja świętego Stanisława $w$ świetle procedury kanonizacyjnej Kościola dzisiaj $i$ dawniej, Rzym 1953, s. 43: „Mając na uwadze fakt, że Kościół umieścił normy regulujące przeprowadzenie spraw tak beatyfikacyjnych jak i kanonizacyjnych w księdze IV Kodeksu, w której zebrane są przepisy regulujące właśnie postępowanie sądowe, możemy słusznie twierdzić, że tak beatyfikacja jak i kanonizacja są prawdziwym procesem".

$30 \mathrm{Na}$ pojęcie procesu sądowego składa się cztery elementy: 1) spór, którego przedmiot stanowi, ,ius aliquod subiectivum controversum aut factum aliquod iuridicum declarandum", 2) podmiot czynny - sędzia, 3) podmiot bierny - strony spór wiodące, 4) forma zewnętrzna prawem przewidziane czynności; wewnętrzna - sprawa musi być 
2. Podobne stanowisko przy rozwiązaniu tego zagadnienia zajmuje Noval ${ }^{31}$, Krzemieniecki ${ }^{32}$ i Regatillo ${ }^{33}$. Według opinii głoszonej przez tych autorów, sprawy beatyfikacyjne i kanonizacyjne są rozstrzygane na sposób sporu sądowego, ale podług norm o wiele ściślejszych, gdyż dotyczą one rzeczy najważniejszej dla Kościoła - wiary i czci Bogu i świętym należnej ${ }^{34}$. Nic przeto dziwnego, że przepisy prawne są tu surowsze od przepisów sądowych. Dlatego też autorowie ci nazywają proces beatyfikacyjny i kanonizacyjny procesem nadsądowym ${ }^{35}$.

3. Jednakże znaczna część kanonistów wyraża pogląd, że proces beatyfikacyjny i kanonizacyjny nie jest procesem sądowym.

W poczet zwolenników tej opinii zaliczają się tacy autorowie, jak Roberti ${ }^{36}$, Lega-Bartoccetti ${ }^{37}$, Tobin ${ }^{38}$, Bertrams ${ }^{39}$.

rozstrzygnięta na sposób sporu „in contradictorio”- por. Krzemieniecki J., Procedura administracyjna $w$ Kodeksie Prawa Kanonicznego, Kraków 1925, s. 13.

${ }^{31} \mathrm{~N}$ oval J., Commentarium Codicis Juris Canonici, lib. IV De Processibus, pars I De Iudiciis, Augustae-Taurinorum-Romae 1920, s. 2 n.

32 Krzemien iecki J., op. cit., s. 14.

33 Regatillo E. F., Institutiones Iuris Canonici, t. II, Santander $1861^{6}$, s. $242,437$.

34 N ov a 1 J., op. cit., s. 3: „Pars secunda praebet leges de causis beatificationis Servorum Dei, et canonizationis Beatorum, id est, de modo disceptandi et resolvendi in contradictorio ad instar iudicij sed ad normas longe rigidiores...". Por. także Krzemieniecki J., op. cit., s. 14; Regatillo E. F., op. cit., t. II, s. 242.

${ }^{35} \mathrm{~N}$ oval J., op cit., s. 2: ,...processus est... b) ultraiudicialis, qui in causis Sanctorum adhibetur..."; $\mathrm{Krz}$ e mi e ni e cki J., op. cit., s. 14: „Sprawy te (beatyfikacji i kanonizacji) mają być również rozstrzygane na kształt sporu sądowego, lecz według norm o wiele sciślejszych... Część tę możnaby zatytułować o procesach nadsądowych".; R e g ati11 o E. F., op. cit., t. II, s. 437: „Processus ultraiudicialis vocari potest (in causis beat. et canonizat.), ob eius rigorem maximum...".

36 Roberti F., op. cit., s. 31 .

${ }^{37} \mathrm{Lega-Bartoccetti,} \mathrm{Commentarius} \mathrm{in} \mathrm{Iudicia} \mathrm{Ecclesiastica,}$ t. I, Romae 1950, s. 2: ,...inde habetur processus vel iudicialis vel extrajudicialis qui distinguitur in administrativum, disciplinarem, informativum et in alias huiusmodi appellationes...". 
Jone $^{40}$ i Konieczny ${ }^{41}$. Uzasadnienie tego zapatrywania podaje Roberti ${ }^{42}$. Uważa on, że proces beatyfikacyjny nie może być traktowany jako proces sądowy, gdyż różni się od niego w sposób istotny ${ }^{43}$. Postępowanie beatyfikacyjne i kanonizacyjne przybiera bowiem charakter procesowy jedynie $w$ tym celu, by na tej drodze łatwiej dojść do lepszego i jaśniejszego poznania świętości sługi Bożego. W procesie beatyfikacyjnym i kanonizacyjnym nie ma jednak ani właściwego sporu, ani też stron procesowych w ścisłym znaczeniu ${ }^{44}$. Decyzję, którą wydaje kampetentna władza w tych sprawach, można zaledwie przyrównać do wyroku stwierdzającego $w$ procesie sądowym ${ }^{45}$. Zdaniem tego autora, procesu beatyfikacyjnego i kanonizacyjnego nie można również nazywać procesem nadsądowym, ponieważ różni się on od procesu sądowego więcej niż proces administracyjny ${ }^{46}$.

3a Tobin. T. J., De officiali curie dioecesanae, Romae 1936, s. 169: „...nam causae beatificationis Servorum Dei et canonizationum Beatorum iudicia proprie dicta non sunt".

39 Bertrams W., De potestate iudiciali-administrativa in Ecclesia, Periodica, XXXIV (1945) 228: „Ita etiam adhibentur (formae iudiciales) in negotiis natura sua non iudicialibus... e. g. in causis beatificationis Servorum Dei et canonizationis Beatorum...".

40 Jone H., Conımentarium in Codicem Iuris Canonici, t. IIT, Taurini-Romae 1955, s. 13: ,...huiusmodi causae (beatificationis et canonizationis) neque dici possunt iudicia ecclesiastica...".

$41 \mathrm{~K}$ onieczny K., Strona formalne postępowania o stwierdzenie zgonu $w$ prawie kanonicznym, Ateneum Kapłańskie, LI (1949) 82: „...sprawy zaś kanonizacyjne nie są procesami w ogóle, jedynie pewną imitacją procesu...". Wydaje się, że przytoczony Autor chociaż odwoluje się do opinii Robertiego, jednak w swoich poglądach idzie dalej od tego kanonisty, gdyż uważa, że sprawy beatyfikacyjne nie są nawet procesem.

42 R oberti F, op. cit., s. 30-32.

43 Ibid., s. 31: ,...quod toto coelo differunt ab istis...".

44 Roberti F., op. cit., s. 31: „Hic enim nec de lege exsequenda, nec de iuribus subiectivis defendendis agitur; nec actor proprie nec conventus habetur...".

45 Ibid.: „Iudicim a legitima auctoritate prolatum vix sententiam declaratoriam analogice imitatur".

46 Ibid., s. 32: „Unde patet hanc figuram processus nec „ultraiudicialem" posse appellari...". 
4. Zbliżony pogląd na omawianą kwestię wyraża również Dallari ${ }^{47}$. Twierdzi on, że chociaż sprawy sporne, stanowiące przedmiot procesu sądowego nie obejmują swym zakresem spraw beatyfikacyjnych, to jednak sam proces beatyfikacyjny wykazuje duże podobieństwo do procesu karnego, w którym chodzi o stwierdzenie karnej bezprawności czynu, wynikłego z winy nieumyślnej (ex culpa) ${ }^{48}$ na skutek zaniedbania przez sprawcę należytej staranności, jakiej od niego domagał się prawodawca ${ }^{49}$. Wprawdzie każdy $\mathrm{z}$ tych procesów posiada cel bezpośredni zupelnie odmienny, gdyz w jednym chodzi o wymiar kary - w drugim o wyniesienie na ołtarze, jednakże można dopatrzyć się analogii w pośrednim celu tych procesów. Zarówno bowiem $\mathrm{w}$ procesie beatyfikacyjnym, jak i w procesie karnym dochodzenie zmierza ku dokładnemu wyświetleniu zachowania się określonej osoby w przeszłości, z tą różnicą, że $\mathrm{w}$ procesie beatyfikacyjnym czyni się dochodzenie celem stwierdzenie, czy postępowanie sługi Bożego przewyższało sposób działania zwykłych ludzi, natomiast w procesie karnym, gdy chodzi o karną bezprawność czynu pochodzącego $\mathrm{z}$ winy nieumyślnej przez zaniedbanie należytej staranności (ex culpa ob omissionem debitae diligentiae) - śledztwo dotyczy stopnia owego zaniedbania, które kwalifikuje postępowanie sprawcy poniżej roztropnego i przezornego działania zwykłych ludzi ${ }^{50}$.

47 Dallari G., De nautra causarum beatificationis, Ephemerides Iuris Canonici, IV (1948) 587-593.

48 M y r c h a M., Prawo Karne, t. II, Warszawa 1960, s. 274: „Do zaistnienia przestępstwa konieczne są: bezprawność, to jest wykonanie lub zaniechanie czynności zabronionej lub nakazanej przez ustawę pod sankcją karną oraz zawinienie - wina sprawcy...".

49 D a 11 ar i G., op. cit., s. 587: „Nunc nobis submisse videtur analogiam hae pervestigationes praebere, debita reverentia ac proportione servata, cum processu poenali, in casibus ubi agitur de delicto ex culpa ob omissionem debitae diligentiae...".

50 Ibid.: „,...de disceptatione circa modum se gerendi in praeterito alicuius hominis, et de aestimatione an ipse vixerit extra cotidianam consuetudinem se gerendi hominum viatorum... ubi agitur de delicto ex cupla ob omissionem debitae diligentiae et aestimatur an reus se gesserit extra communem prudentem modum se gerendi hominum mediae diligentiae...". 
Ponadto autor ten uważa, że proces beatyfikacyjny upodabnia się do procesu karnego dzięki solennościom aktów procesowych oraz powtarzaniu badań ${ }^{51}$.

5. Niektórzy spośród kanonistów, jak Bernardini ${ }^{52}$, Johson ${ }^{53}$, Coronata ${ }^{54}$ i Garceau ${ }^{55}$ utrzymują, że proces beatyfikacyjny i kanonizacyjny posiada charakter administracyjny. Wprawdzie przybiera on zewnętrzną formę sądową, niemniej jednak, zdaniem wymienionych autorów, jego natura jest administracyjna ${ }^{56}$.

6. $\mathrm{Z}$ zestawienia dotychczasowych opinii na temat natury procesu beatyfikacyjnego wynika, że zawiera on elementy charakterystyczne zarówno procesom sądowym, jak i administracyjnym. Wychodząc $z$ tych założeń Melichar twierdzi,

51 Ibid:: „Quae similitudo... nobis videtur ad exarandam formam processus, qui progreditur per solennes actus processuales... et praecipue quod attinet ad reiterationes pervestigationum...".

52 Bernardini C., De postulatore in causis Servorum Dei, Apollinaris, IX (1936) 193-195.

${ }^{53}$ Johnson J., De distinctione inter potestatem iudicialem et potestatem administrativam in iure canonico, Apollinaris, IX (1936) 261.

54 M. Conte a Coronata, Institutiones Iuris Canonici, t. III De Processibus, Taurini-Romae $(1956)^{4}$, s. 5 .

${ }_{55} \mathrm{G}$ a r c e a u Ch., Le rôle du Postulateur dans les procès ordinaires de béatification, Rome 1954, s. 8-11.

56 Bernardini C., op. cit., s. 193: „Causae beatificationis Servi Dei et canonizationis Beati... cum naturam administrativam retineant, quandam tamen iudicialem formam induunt."; Johnson J., op. cit., S. 261: „Normae processuales... adhibentur in actibus qui naturam administrativam ex toto vel ex parte habent e. g. ...in causis Sanctorum (can. 1999)..."; M. Conte a Coronata, op. cit., s. 5: „...solum processus de quibus in prima parte... processus iudiciales appellabimus, alios processus extraiudiciales aut administrativos."; G a r ce a u Ch., op. cit., s. 11: „En conclusion, il faut donc dire que ces procès ont un contenu administratif... Cependant, le proces, quoique sans fond contentieux, est célébré en pleine forme judicielle. Ils sont donc analogiquement judiciels et formellement administratifs".

Podobne stanowisko do powyższego zająi niegdys Roberti w artykule: De variis rationibus procedendi hodie vigentibus in iure canonico, Apollinaris, IX (1936) 465: „Ultimo recensendi sunt processus beatificationis et canonizationis qui etsi ad actus administrativos diriguntur, veras quoque normas processuales habent...". 
że postępowanie beatyfikacyjne opiera się na różnych̆ typach procesowych ${ }^{57}$. W przeciwienstwie bowiem do państwowych procesów administracyjnych, które zawierają elementy procesu sądowego, proces beatyfikacyjny $w$ ramach prawdziwych czynności sądowych posiada elementy pomocnicze, administracyjne. To dziwne połączenie czynności sądowych i administracyjnych służy jednemu celowi - ostatecznej decyzii papieża ${ }^{58}$.

Do podobnego wniosku doszedł również Blaher, który już wyraźnie twierdzi, że proces beatyfikacyjny posiada charakter sądowo-administracyjny ${ }^{59}$. Ponieważ autor ten szczegółowo uzasadnil swój pogląd, wypada przyjrzeć się sposobowi jego dowodzenia.

a) $\mathrm{W}$ procesie beatyfikacyjnym, zdaniem tego autora, nie ma elementu spornego, o którym mowa w kan. $1552 \S 2$. Wprawdzie toczy się $\mathrm{W}$ nim spór między postulatorem a promotorem wiary, jednakże nie odpowiada on wymogom powyższego kanonu. W procesie tym bowiem nie chodzi o uznanie lub przywrócenie praw osoby fizycznej lub moralnej, ani też o ustalenie faktów prawnych albo o wymierzenie względnie stwierdzenie zaciągniętej kary ${ }^{60}$.

$57 \mathrm{M}$ elichar E., Der Selig - und Heiligsprechungsprozess vom Standpunkt einer prozessualen Typenlehre, Zeitschrift für katolische Theologie, LXX (1948) 212-223.

58 Ibid., s. 223: „Das SuH-Verfahren erweist sich also ein Kombinat von Teilverfahren, die sich an die verschiedensten Prozestypen anlehnen".

59 Blaher D. J., The Ordinary Processes in Causes of Beatification and Canonization, Washington 1949, s. 58: ,...and hence can be justly called a judicial-administrative process". Wydaje sie, że zbliżony pogląd na tę kwestię wyraża również Klaus Mörsdorf (Rechtsprechung und Verwaltung im kanonischen Rechts, Freiburg i. B. 1941). Wykonywanie władzy sądowniczej przez organa administracyjne nazywa on sądownictwem administracyjnym (iudicatio administrativa). Otóź, jego zdaniem, wladzę tę wykonuje Kongregacja Obrzędów w sprawach beatyfikacji i kanonizacji.

60 B l a her D.J., op. cit., s. 55: ,... the contentious or criminel element... is lacking in the beatification processes". 
b) W procesie beatyfikacyjnym nie występuje również powód i pozwany $w$ znaczeniu spotykanym $w$ procesie spornym ${ }^{61}$.

c) Analiza wewnętrznej natury ostatecznej decyzji wydawanej $\mathrm{w}$ procesie beatyfikacyjnym i kanonizacyjnym wskazuje na jej bardzo małe podobieństwo do wyroku $w$ procesie sądowym ${ }^{62}$.

d) Twierdzenie, że proces beatyfikacyjny nie ma charakteru sądowego $w$ sensie ścisłym, nie jest równoznaczne $z$ pominięciem oczywistego faktu, że całe postępowanie beatyfikacyjne ujęte zostało $\mathrm{w}$ formie sądowej ${ }^{63}$. Proces ten raczej ma na celu przeprowadzenie dochodzenia ,de veritate" niż „de iustitia et iure". Stąd całe śledztwo nosi tu charakter sądowy, gdyż forma sądowa jest $\mathrm{w}$ tym procesie obligatoryjna ${ }^{64}$.

e) Ponieważ jednak proces beatyfikacyjny nie rozpoczyna się od skierowania skargi do kompetentnego trybunału, a ostateczna decyzja zależy od dobrowalnej zgody papieża, dlatego też, zdaniem Blahera, postępowanie beatyfikacyjne nosi również charakter administracyjny ${ }^{65}$.

f) Z przytoczonych powyżej szczegółowych twierdzeń Blaher wyciąga wniosek, że proces beatyfikacyjny posiada charakter sądowo-administracyjny. $O$ ile bowiem $z$ punktu widzenia formy proces ten ma charakter sądowy, o tyle $\mathbf{z}$ punktu widzenia ostatecznej decyzji posiada charkter administracyjny ${ }^{66}$.

61 Ibid., s. 56 .

62 Ibid., s. 56n.

63 Ibid., s. 57: „To say that the beatification processes are not judicial processes in the strict and commonly accepted sense of the term is not to overlook the fact that they are clothed in full judicial form...".

64 Ibid.

65 B laher D. J., op. cit. S. 57: „On the other hand, since these processes do not originate from a contentious or criminal action, and since the final judgment of beatification or canonization comes from the kening concession and independent decision of the Supreme Pontiff, they have an administrative content".

66 Ibid.: „Inasmuch as these processes, from the viewpoint of form are overwhelmingly judicial and, from the viewpoint of the final decision rendered, are administrative in charakter, they may properly 
$\mathrm{Na}$ pytanie czy termin „sądowo-administracyjny" nie jest w sobie sprzeczny - Blaher odpowiada przecząco. Proces beatyfikacyjny nie jest bowiem ani ściśle sądowym, ani też ściśle administracyjnym. Słuszność tego poglądu, zdaniem tego autora, potwierdza również prawodawca, gdyż omawia proces beatyfikacyjny i kanonizacyjny pomiędzy procesami sądowymi i administracyjnymi. Umiejscowienie tego procesu w Kodeksie Prawa Kanonicznego nie jest czysto przypadkowe. Umieszczano go bowiem $w$ rozmaitych miejscach Kodeksu, az wreszcie zajął obecne położenie ${ }^{67}$.

W sposób pośredni fakt ten dowodzi tezy, że nawet kodyfikatorzy nie byli pewni sądowego albo administracyjnego charakteru tego procesu ${ }^{68}$. Jeżeli jednak postępowanie beatyfikacyjne i kanonizacyjne umieścili między procesami sądowymi i administracyjnymi, widocznie dostrzegli w nim elementy wspólne wymienionym procesom ${ }^{69}$.

g) Zdaniem Blahera, jego tezę o sądowo-administracyjnym charakterze procesu beatyfikacyjnego potwierdzają również decyzje Stolicy Apostolskiej, wydawane w tych sprawach, gdyż niejednokrotnie noszą one nazwę: „decretoria sententia" 70 .

Według tego autora dyskusja nad naturą procesu beatyfikacyjnego nie stanowi jedynie spekulatywnego dociekania,

be referred to as judicial-administrative processes"; s. 58: ,...the processes is a mixture of both the judicial and the administrative, and hence can be justly called a judicial-administrative prosess".

67 Por. Roberti F., Codicis Iuris Canonici Schemata, lib. IV De Processibus, In Civitate Vaticana 1940, s. 7.

68 B laher D. J., op. cit., s. 55: "In this regard it is interesting to note that in the earlier drafts of the Fourth Book of the Code parts two and three were interchanged, an indication, perhaps, that the codifiers themselves were at first not perfectly clear on the nature of the beatification processes".

69 Ibid., s. 58.

70 Por. Acta in Sollemni Canonizatione Beatae Catherinae Labouré, Virginis, AAS, XXXIX (1947) 377 - gdzie w rubryce do decyzji kanonizacyjnej czytamy: „Antequam Summus Pontifex decretoriam sententiam ferret, qua B. Catherina Labouré... sanctitatis decore exornatur...".

6 - Prawo Kanoniczne $\mathrm{nr} 1-2$ 
pozbawionego praktycznego znaczenia. Jeżeli bowiem staniemy na stanowisku, że forma zewnętrzna postępowania beatyfikcyjnego jest $\mathrm{w}$ pelni sądowa, wówczas przepisy regulujące postępowanie sądowe stanowić będą dla procesu beatyfikacyjnego „leges latae in similibus", w wypadku zaistnienia luk prawnych ${ }^{71}$.

7. Wreszcie $z$ wypowiedzi niektórych kanonistów można wnioskować, że traktują oni proces beatyfikacyjny i kanonizacyjny jako proces specjalny. W poczet zwolenników tej opinii wchodzi Wernz-Vidal 72, Suârez i Mitri ${ }^{33}$.

8. Różnice, jakie zarysowują się $w$ wypowiedziach kanonistów na temat natury postępowania w sprawach beatyfikacyjnych i kanonizacyjnych, dobitnie podkreślają specyficzny charakter tego procesu.

A. Proces beatyfikacyjny i kanonizacyjny nie posiada charakteru ściśle sądowego.

a) W procesie sądowym wszelkie dochodzenia zmierzają do rozstrzygnięcia sporu, który zaistnial między stronami na skutek naruszenia przez jedną $z$ nich uprawnień drugiej strony lub do ustalenia faktów prawnych, albo też do wymie-

71 Por. kan. 20; B 1 a h e r D. J., op. cit., s. 58.

72 Wernz-Vidal, Jus Canonicum, t. IV De Processibus, Romae 19492, s. 717: „Quamvis in his causis non agatur sensu stricto de processu quoddam contentioso seu civili, in quo de iure privatarum personarum agatur, cum mortuis iura non sint, nec viventes ius habent..., tamen ad decernendos alicui Servo Dei honores beatificationis, aut alicui Beato solemniorem honorem canonizationis, methodus quaedam adhibenda fuerit statuta ad similitudinem ordinis iudiciarii, ne in causis tanti momenti minus caute procederetur, non immerito iste processus aliis specialibus processibus connumeratur...".

73 Suárez E., De remotione parochorum aliisque processibus tertiae partis Lib. IV. Cod. Iur. Can., Romae-Neapoli 19592, s. 2, odn. 2: „Legislatorem voluisse processus proprie vocare... processus iudiciales, processus in causis beatificationis et canonizationis, et aliquos speciales processus quos in tertia parte recenset". M itri A., De figura juridica postulatoris, Roma 1962, s. 64: ...processus beatificationis et canonizationis veri processus ecclesiastici sunt, etsi sui generis..." - patrz rękopis str. 18. 
rzenia lub deklaracji zaciągniętej kary ${ }^{74}$. Tymczasem $w$ procesie beatyfikacyjnym nie dochodzi się praw subiektywnych $\mathrm{w}$ ścisłym znaczeniu ${ }^{75}$. Prawo podmiotowe jest bowiem obwarowane ustawą, a naruszenie go przez inną osobę uprawnia do wytoczenia skargi przeciwko niej przed sądem ${ }^{76}$. W tym znaczeniu nikt $w$ procesie beatyfikacyjnym nie jest uprawniony do wniesienia skargi przed kompetentnym trybunałem, celem uznania sługi Bożego za Błogosławionego, ale może jedynie prosić właściwy trybunał, by rozpatrzył sprawę świętości sługi Bożego ${ }^{77}$.

Wprawdzie świętość sługi Bożego, skoro zostanie potwierdzona przez najwyższą władzę Kościoła, a więc Ojca św., wywoluje skutki prawne ${ }^{78}$, jednakże nie stanowi ona faktu prawnego w znaczeniu spotykanym w prawie ${ }^{79}$. Swiętość bowiem $z$ jednej strony nie jest zdarzeniem zupełnie niezależnym od działania człowieka (zdarzenie prawne), z drugiej zaś nie sta-

74 Por. kan. 1552 \& 2 .

75 Chodzi tu o ,ius subiectivum proprie dictum, quod actione munitur" zgodnie $\mathrm{z}$ zasadą wyrażoną $\mathrm{w}$ kan. 1667: „Quodlibet ius non solum actione munitur, nisi aliud expresse cautum sit, sed etiam exceptione, quae semper competit et est suapte natura perpetua". Por. Johnson J., op. cit., s. 265; Lega-Bartoccetti, op. cit., t. I, s. 3.

76 Roberti F., op. cit., t. I, s. 62 : „Nam quodlibet ius subiectivum innititur iure obiectivo seu lege, sicut quaelibet actio a iure obiectivo procedit.”; Lega-Bartoccetti, op. cit., t. I, s. 355: „..iura non posse deduci in iudicium nisi munita sint actione...".

77 Kan. 2003 \& 1: „Quivis fidelis vel legitimus Christifidelium coetus ius habet petendi ut causa apud tribunal competens instruatur". Podanie postulatora o wszczęcie procesu nosi nazwę: "Supplex libellus" por. $\mathrm{Machejek-Padacz}$, Sprawy beatyfikacyjne na terenie diecezji, Poznań 1957, s. 357. Pewnego rodzaju analogia istniałaby $z$ postępowaniem super rato, gdzie według kan. 1973: „Soli coniuges ius habent petendi dispensationem..." - por. Cas ori a J., De matrimonio rato et non consummato, Romae 1959, s. 111.

78 Kan. $1277 \S 2$ : „In album Sanctorum canonice relatis cultus duliae debetur...".

79 Por. Michiels G., Principia generalia de personis in Ecclesia, Parisiis-Tornaci-Romae 1955, s. 568: „Facta, quae cum contingunt, ad normam legis jura pariunt... facta juridica nuncupantur". 
nowi tylko i wyłącznie przejawu świadomej woli ludzkiej, podjętej w tym celu, by wywołać skutki prawne ${ }^{80}$.

b) W postępowaniu beatyfikacyjnym i kanonizacyjnym trudno również wskazać na strony procesowe w znaczeniu spotykanym $\mathrm{w}$ procesie spornym lub karnym ${ }^{81}$. Chociaż bowiem $\mathrm{w}$ przepisach traktujących o procesie beatyfikacyjnym Kodeks wyraźnie mówi „de actore”, ale rola powoda jest tu zupełnie inna niż $w$ procesie spornym ${ }^{82}$. Powód $w$ procesie beatyfikacyjnym nie dochodzi swoich praw, a jest jedynie uprawniony do skierowania prośby do kompetentnego trybunału, aby ten rozpatrzył sprawę świętości sługi Bożego ${ }^{83}$.

Gdybyśmy postępowaniu beatyfikacyjnemu i kanonizacyjnemu przyznali charakter sądowy, z konieczności musielibyśmy się dopatrzyć w nim rzeczywistych stron procesowych. Powstaje jednak pytanie, czy osoby proszące o beatyfikację wraz z postulatorem z jednej strony, a promotora wiary i cały Kościól powszechny $z$ drugiej strony - można nazwać stronami procesowymi $w$ znaczeniu przyjętym $w$ procesie sądowym ${ }^{84}$. Wydaje się, że tego rodzaju zaopatrywanie obala tezę o sądowym charakterze procesu beatyfikacyjnego. $\mathrm{W}$ procesie sądowym strony cechuje prawny stosunek równorzędności ${ }^{85}$. Tymczasem tej równorzędności nie dostrzegamy w procesie beatyfikacyjnym. Przeto wydaje się, że pod tym względem proces beatyfikacyjny upodobniłby się do procesu administra-

${ }^{30}$ Por. Di ek am p F., Theologiae Dogmaticae Manuale, t. IV, Parisiis-Tornaci-Romae - Neo Eboraci (1943), s. 562: „Ratio interna, cur Sancti cultu sunt digni, est excellentia virtutum, ad quam gratia divina adjuti ascenderunt...".

81 Galass i I., Quaestiones de processibus beatificationis et canonizationis, Ephemerides Juris Canonici, III (1947) 150.

82 Kan. $2004 \S 1$ : „Actor potest agere per se vel per procuratorem...".

83 Kan. 2003; G a r ce a u x Ch., op. cit., s. 34.

84 L i s ow ski S., op. cit., s. 43: „Stronami w procesie kanonizacyjnym są $z$ jednej strony ci, którzy czynią starania o przeprowadzenie beatyfikacji czy kanonizacji, z drugiej zaś strony Stolica Apostolska lub Kościól Powszechny".

85 Petrani A., Sprawy sporne oraz sposób ich załatwiania w Kosciele, Ateneum Kapłańskie, XLVIII (1948) 61-64. 
cyjnego, w którym występują strony nie będące ze sobą w prawnym stosunku równorzędności ${ }^{86}$.

c) W procesie beatyfikacyjnym biorą udział sędziowie ${ }^{87}$. Jest rzeczą charakterystyczną, że prawodawca traktuje ich $\mathrm{w}$ podobny sposób jak sędziów $\mathrm{w}$ procesach sądowych ${ }^{88}$. Stwierdzenie powyższego faktu mogłoby nasuwać przypuszczenie, że proces beatyfikacyjny jest procesem sądowym, ponieważ $\mathrm{w}$ procesie administracyjnym występuje $\mathrm{w}$ zasadzie przełożony „superior" ${ }^{89}$.

Trzeba jednak stwierdzić, że $\mathrm{z}$ faktu udziału sędziów w procesie beatyfikacyjnym i kanonizacyjnym nie można wnosić - jego sądowym charakterze. Znane są bowiem wypadki, w których sędziowie występują również w niektórych procesach administracyjriych ${ }^{90}$.

86 Ibid., s. 64 .

87 Por. kan. 2037 \& 1, 2040, 2092.

88 M elich a r E., op. cit., s. 221. O sędziach sądów polubownych por. Myrcha M. A., Sądy polubowne w prawie kanonicznym, Lublin 1948 , s. $119-168$.

${ }_{89} \mathrm{Na}$ ogół autorzy $\mathrm{w}$ procesie administracyjnym wyodrębniają następujące elementy: podmiot czynny - ordynariusz jako przelożony; podmiot bierny - wierni; przedmiot - obowiązki stanu lub występki urzędników; forma wewnętrzna nie jest sporna; zewnętrzna - prawem określony sposób postępowania - por. Krzemieniecki J., op. cit., s. 16 .

90 Por. Regulae servandae S. Congregationis de disciplina Sacramentorum in processibus super matrimonio rato et non consummato, cap. IV. De officio judicis et tribunalis ministrorum, AAS, XV (1923) 369-913. Jednakże proces ten nie jest sądowy, gdyż we wstępie dekretu: „Catholica doctrina" z dnia 7 maja 1923 r, który wprowadził wymienione postępowanie, czytamy: „...quod huismodi causae, utpote quae non promoventur $a b$ actione iudiciali contentiosae aut criminali, sed ex benigna concessione Sanctae Sedis annuentis oratoris precibus, non sunt vere iudiciales, sed magis gratiosae seu administrativae". - por. B is k u pski S., Prawo mażeńskie, t. II, Olsztyn 1960, s. 408; Casoria J., op. cit., s. 121.

Podobny wypadek ma miejsce również w postępowaniu dyscyplinarnym ,super nullitate $s$, ordinationis vel onerum sacris ordinibus inhaerentium" - por. Regulae servandae in processibus super nullitate s. ordinationis vel onerum sacris ordinibus inhaerentium, cap. V De 
d) Postępowanie beatyfikacyjne i kanonizacyjne zawiera również prawem przepisane czynności zarówno osób wystẹpujących $w$ procesie, jak i trybunału. Trzeba zaznaczyć, że formalności przewodu beatyfikacyjnego są większe i bardziej skomplikowane niż w procesie spornym. Pod tym względem proces beatyfikacyjny i kanonizacyjny przewyższa procesy sądowe.

Jednakże forma postępowanie nie decyduje o sądowym charakterze procesu beatyfikacyjnego i kanonizacyjnego ${ }^{91}$. Normy procesowe mogą bowiem być skrócone $w$ procesie sądowym, jak to ma miejsce np. w małżeńskim procesie dokumentalnym ${ }^{92}$, a mogą występować $w$ całej rozciągłosści $\mathrm{W}$ czynościach administracyjnych ${ }^{93}$. Istota procesu sądowego polega bowiem na tym, że odbywa się on w sposób sporny

officio judicis et tribunalis ministrorum, AAS, XXIII (1931) 457. O naturze tego procesu tak pisze Lega-Bartoccetti, op. cit., t. III, Appendix I, s. 284: „Certe iudiciarius seu pure contentiosus non est...; est autem vero sensu processus administrativus seu oeconomicus, qui videtur melius componi cum causis mere spiritualibus".

91 Dawniejsi kanonis̉ci, jak np. Cappello F., De Curia Romana, Romae 1911, s. 50nn i M a o to F., Institutiones Iuris Canonici, t. I, Matriti 1919, s. 863 dopatrywali się różnicy między procesem administracyjnym i sądowym $w$ formie postępowania. Jednakże opinia ta obecnie została zarzucona. Współcześni kanoniści upatrują tej różnicy w naturze spraw, chociaż żywo dyskutują nad tym problemem, które sprawy wymagają postępowania sądowego, a które administracyjnego por. Mö rs dorf $\mathrm{K}$., De relationibus inter potestatem administrativam et iudicialem in iure canonico, Analecta Gregoriana, LXIX (1955) 399418; Goyeneche S., De distinctione inter res iudiciales et administrativas in Jure Canonico, ibid.; Dos Palmares, De processu summario ex notorio - administrativo in iure canonico, Romae 1956; S uá rez E., op. cit., s. 3.

92 Kan. 1990. Według odpowiedzi Komisji Interpretacyjnej z dnia 6 grudnia 1943 r. (AAS, XXXIV (1944) 94) proces ten ma charakter sadowy: „Utrum processus, de quo in can. 1990, sit ordinis iudicialis, an administrativi. R. - Affirmative ad primam partem, negative ad secundam".

93 Por. kan. 1962, 1985, $1993 \S 3,2142$; J ohns on J., op. cit., s. 261; Roberti F., op. cit., t. I, s. 112. 
„in contradictorio", a więc że sędzia rozstrzyga sprawę między powodem a pozwanym, względnie oskarżycielem a oskarżonym ${ }^{94}$.

B. Proces beatyfikacyjny i kanonizacyjny nie posiada również natury ściśle administracyjnej.

a) W przeciwieństwie do władzy sądowej, która w zasadzie stoi na straży ochrony praw, władza administracyjna broni interesu prawnego (interesse legitimum) $\mathrm{w}$ wypadku, gdy ustawa nie przewiduje powództwa sądowego ${ }^{95}$. Wychodząc $z$ tego założenia należy stwierdzić, że nikt $z$ wiernych nie posiada własnego interesu prawnego, by sługa Boży został uznany przez najwyższą władzę $\mathrm{w}$ Kościele za błogosławionego czy też świętego. Brak elementu interesu prawnego w procesie beatyfikacyjnym i kanonizacyjnym sprawia, że nie ma on charakteru administracyjnego.

b) Procesy administracyjne są zasadniczo ustanowione w tym celu, by określone sprawy można było rozstrzygnąć w sposób szybszy, skrócony ${ }^{96}$. Tymczasem proces beatyfikacyjny i kanonizacyjny trwa bardzo długo. Przyśpleszenie tych spraw zależy nie tylko od sprawnego działania trybunałów, ale również od wiernych, którzy przez modlitwy zanoszone do Boga za wstawiennictwem sługi Bożego uzyskują sobie nadzwyczajne laski i cuda, przyczyniając się $\mathrm{w}$ ten sposób do przyśpieszenia ostatecznej decyzji papieża ${ }^{97}, \mathrm{Z}$ tego przeto względu proces ten różni się wielce od procesów administracyjnych.

94 Krzemieniecki J., Glówne warunki ważności kanonicznego procesu administracyjnego, Kraków 1930, s. 80.

95 J o h n s o n J., op. cit., s. 266: „Ad potestatem iudicialem pertinet tuitio iurium et ad potestatem administrativam tuitio interesse ...quae actione iudiciali non gaudet". Interes prawny (interesse legitimum w odróżnieniu od interesse simplex) w nauce prawa określa się jako: "directum et immediatum ad quod tuendum actio administrativa datur" - por. John s o n J., ibid., s. 265.

96 Petrani A., op. cit., s. 64.

97 Por. Bar J., Uwagi na temat procesu beatyfikacyjnego, Ateneum Kapiańskie, IV (1957) 293-299. 
C. Proces beatyfikacyjny i kanonizacyjny nie posiada także charakteru sądowo-administracyjnego.

Wbrew temu, co utrzymuje Blaher ${ }^{98}$, trzeba stwierdzić, że porządek sądowy (ordo iudiciarius) i administracyjny wykluczają się wzajemnie ${ }^{99}$. Między tymi procesami bowiem zachodzi relacja dysjunkcji ${ }^{100}$. Dlatego też argumenty przytaczane za sądowo-administracyjnym charakterem procesu beatyfikacyjnego i kanonizacyjnego nie są przekonywujące.

Ponadto argument przytoczony przez Blahera, że decyzje wydawane przez Stolicę Apostolską $w$ tych sprawach noszą nazwę „decretoria sententia” - nie jest zupełnie słuszny ${ }^{101}$. W podanym przez niego wypadku, a chodzi tam o dekret kanonizacyjny błogosławionej Katarzyny Labouré, wprawdzie zostało użyte wyrażenie „decretoria-sententia", ale mieści się ono. $w$ rubryce $i$ nie stanowi właściwego tekstu decyzji ${ }^{102}$.

D. Wydaje się, że na podstawie przytoczonych powyżej argumentów można chyba twierdzić, że natura procesu beatyfikacyjnego i kanonizacyjnego jest odrębna zarówno od procesów sądowych, jak i administracyjnych. Jest to specjalny ro-

98 B la her D. J., op. cit., s. $57 \mathrm{n}$.

99 Bertrams W., op. cit., s. 224: „Disiunctio sit inter ordinem iudicialem et ordinem administrativum. Haec disiunctio habetur completa... Ordo iudicialis ordinem administrativum excludit et vice-versa".

100 Wydaje się, że dysjunkcja ta jest analogiczna do logicznej dysjunkcji zdań „Dpq" - por. Czeżowski T., Gtówne zasady nauk filozoficznych, Wrockaw 1959, s. 69; Grygor owicz J., Zarys logiki dla prawników, Warszawa 1962, s. 77 (alternatywa rozłączna $\mathrm{p} \div \mathrm{q})$.

101 Blaher D. P., op. cit., s. 58.

102 Por. AAS, XXXIX (1947) 377 n.: „Antequam Summus Pontifex decretoriam sententiam ferret...”. Natomiast $w$ orzeczeniu czytamy: „Ad honorem Sanctae et Individuae Trinitatis, ad exaltationem Fidei Catholicae et Christianae religionis augmentum... Beatam Catharinam Labouré virginem, sanctam esse decernimus et definimus ac Sanctorum Cathologo adscribimus". 
dzaj procesu, w którym istnieje swoiście pojęty spór, strony występujące $\mathrm{w}$ toku całego przewodu, trybunal oraz forma zewnętrzna postępowania. Wielka liczba procesów przewidzianych prawem, wchodzących w skład całego przewodu beatyfikacyjnego dowodzi, jak ostrożnie postępuje Kościół, zanim ogłosi kogoś jako błogosławionego a następnie jako świętego ${ }^{103}$.

Proces beatyfikacyjny i kanonizacyjny posiada specyficzny cel. Nic przeto dziwnego, że posiada on właściwą sobie naturę, której w sposób adekwatny nie odpowiada ani charakter procesu sądowego lub administracyjnego, ani też połączenie obu tych procesów.

Za specyficzną naturą procesu beatyfikacyjnego i kanonizacyjnego możnaby za Benedyktem XIV przytoczyć ten argument, że sprawy te są święte, przy rozpatrywaniu których kardynałowie są tylko doradcami, a sędzią jest tylko Ojciec św. ${ }^{104}$. Dlatego słuszne stanowisko zajął prawodawca,

103 Przez beatyfikację należy rozumieć akt prawny, na mocy którego Ojciec św. zezwala na oddawanie kultu publicznego słudze Bożemu, ograniczonego do pewnego miejsca lub określonej liczby osób, albo jedynie $w$ ściśle określony sposób. Natomiast przez kanonizację należy rozumieć ostateczną decyzję Ojca św., w której stwierdza, że sługa Boży znajduje się w niebie i nakazuje oddawać mu cześć publiczną w całym Kościele - por. kan. $1277 \S \S 1-2$; Benedictus XIV, op. cit., I, 42; Re iffenstuel A., Jus canonicum universum, t. V, Parisiis 1889 , tit. $45, \S 1, \mathrm{n} .4 ; \mathrm{N}$ a z R., Causes de béatification et de canonisation, Dictionnaire de droit canonique, t. III, Paris 1942, kol. 10; Lis owski J., op. cit., s. 36; Garcea u Ch., op cit. s. 3; Eichmann-Mörsdorf, Lehrbuch des Kirchenrechts, t. III, Paderborn $(1954)^{8}$, s. 252.

Według powszechnego zdania teologów i kanonistów papież ogłaszając kanonizacje jest nieomylny - por. Kieda F., Infallibility of the pope in his decree of canonization, The Jurist, VI (1946) $401-415$.

104 Benedictus XIV, I, 21, 14: ,...quid dicendum est in re nostra quae adeo sancta est, et in qua Cardinales non sunt nisi Consultores et Papa est Judex...".

105 Por. pars Il Lib. IV C.I.C.: „De causis Beatificaticnis Servorim Dei et Canonizationis Beatorum". 
poświęcając postępowaniu w sprawach beatyfikacji i kanonizacji całą część drugą IV księgi Kodeksu Prawa Kanonicznego ${ }^{105}$. Oddzielne potraktowanie tego procesu dowodzi, że jest to specjalny rodzaj procesu kościelnego ${ }^{106}$.

106 O specyficznosci norm prawnych w sprawach beatyfikacji i kanonizacji - por. Crnica A., De canonizatione aequipollenti, Monitor Ecclesiasticus, LXXXVI (1961) 263: „Iam vero leges quae respiciunt beatificationem Servorum Dei et canonizationis Beatorum non sunt mere disciplinares, sed potius ad ius divinum positivum referuntur...". 